\begin{tabular}{|l|l|l||}
\hline \multicolumn{2}{|c|}{ PublisherInfo } \\
\hline \hline PublisherName & $:$ & BioMed Central \\
\hline \hline PublisherLocation & $:$ & London \\
\hline \hline PublisherImprintName & $:$ & BioMed Central \\
\hline \hline
\end{tabular}

\title{
Loopy expression
}

\begin{tabular}{|l|l|l||}
\hline \multicolumn{2}{|c|}{ ArticleInfo } \\
\hline \hline ArticleID & $:$ & 3947 \\
\hline \hline ArticleDOI & $:$ & $10.1186 /$ gb-spotlight-20010104-02 \\
\hline \hline ArticleCitationID & $:$ & spotlight-20010104-02 \\
\hline \hline ArticleSequenceNumber & $:$ & 18 \\
\hline \hline ArticleCategory & $:$ & Research news \\
\hline \hline ArticleFirstPage & $:$ & 1 \\
\hline \hline ArticleLastPage & $:$ & 2 \\
\hline \hline & & RegistrationDate : 2001-01-04 \\
ArticleHistory & $:$ & OnlineDate $\quad$ 2001-01-04 \\
\hline \hline ArticleCopyright & $:$ & BioMed Central Ltd2001 \\
\hline \hline ArticleGrants & $:$ & \\
\hline \hline ArticleContext & $:$ & 130592211 \\
\hline \hline
\end{tabular}




\section{William Wells}

Email: wells@biotext.com

Yeast is unusual in that its transcriptional activators cannot work over long distances. But in the 4 January Nature, de Bruin et al. report that the looping of heterochromatic-like telomere regions corrects this shortcoming (Nature 2001, 409:109-113). They place a binding site for the activator Gal4 downstream of a reporter gene. The site is inactive when the reporter is at an internal chromosomal locus, but active when the gene cassette is placed, in either orientation, near the telomere. Only at the telomere is Gal4 associated with promoter DNA, as assayed by chromatin immunoprecipitation. This leads de Bruin et al. to suggest that telomere looping brings the activator close to the promoter to activate transcription. Such looping may be impossible elsewhere in the yeast genome because yeast lacks either the heterochromatic regions or auxiliary looping proteins present in other species.

\section{References}

1. Separation of DNA binding from the transcription-activating function of a eukaryotic regulatory protein.

2. Nature, [http://www.nature.com/nature/]

3. SIR2 and SIR4 interactions differ in core and extended telomeric heterochromatin in yeast.

This PDF file was created after publication. 